\title{
Chromosomal Location and Inheritance of Stem Rust Resistance Transferred from Hordeum bulbosum into Cultivated Barley $(H$. vulgare $)$
}

\author{
T. Fetch, Jr., P. A. Johnston, and R. Pickering
}

First author: Agriculture and Agri-Food Canada, Cereal Research Centre, Winnipeg, MB, R3T 2M9, Canada; and second and third authors: New Zealand Institute for Crop and Food Research Limited, Private Bag 4704, Christchurch, New Zealand. Accepted for publication 31 October 2008.

\begin{abstract}
Fetch, T., Jr., Johnston, P. A., and Pickering, R. 2009. Chromosomal location and inheritance of stem rust resistance transferred from Hordeum bulbosum into cultivated barley (H. vulgare). Phytopathology 99:339-343.

Stem rust, caused by Puccinia graminis f. sp. tritici, is an important disease on barley (Hordeum vulgare). Host resistance has effectively controlled stem rust, primarily through use of gene Rpg1. However, virulence to Rpgl is present in North America, and a new race (TTKSK, or Ug99) from eastern Africa threatens barley production. A search for novel resistance was previously conducted, and an interspecific barley breeding line (212Y1) with introgressed chromatin from H. bulbosum was identified as carrying resistance to races MCCF and QCCJ. This study evaluated the inheritance of resistance in $212 \mathrm{Y} 1$ using populations from crosses to Morex (Rpg1 donor) and Q21861 (rpg4 donor) and the pathogen races MCCF (avirulent on Rpgl and rpg4) and QCCJ (virulent on Rpgl and avirulent on rpg4), and determined the chromosomal position

of the introgression using genomic in situ hybridization (GISH) and chromosome-specific polymerase chain reaction (PCR)-based markers. Progeny from the 212Y1/Q21861 $\mathrm{F}_{2}$ population segregated for resistant and susceptible plants, indicating different gene loci. Genetic analyses of Morex/212Y1 $\mathrm{F}_{3}$ families fit a 7 homozygous resistant (HR):8 segregating:1 homozygous susceptible (HS) family segregation ratio to race MCCF, indicating that two genes controlled resistance. Plants in segregating families were in 3R:1S (Rpg1), 13R:3S (Rpg1+212Y1), and 1R:3S (212Y1) ratios. Genetic analyses of the same $F_{3}$ families fit a 1HR:2 segregating:1HS family segregation ratio to race QCCJ, indicating monogenic inheritance. Plants in segregating families were in a $1 \mathrm{R}: 3 \mathrm{~S}$ ratio, indicating recessive inheritance in 212Y1. The introgression from $H$. bulbosum into $H$. vulgare was positioned on chromosome 6HS based on GISH and the PCR-based markers. No known stem rust resistance gene has previously been mapped to that region. Thus, it is proposed to name this novel gene from $H$. bulbosum as rpg6.
\end{abstract}

Stem rust, caused by Puccinia graminis Pers.:Pers. f. sp. tritici Eriks. \& E. Henn. is a disease that is found on barley (Hordeum vulgare L.) worldwide. Yield losses up to $15 \%$ have occurred in North America (15), but epidemics on barley have historically been rare unless nearby wheat fields are also severely rusted (16). However, recent epidemics of stem rust on barley in North America occurred from 1989 to 1991, with yield losses of 1 to $3 \%$, attributable to race QCCJ (21). In this instance, spring wheat varieties in the northern Great Plains states were resistant, while barley varieties were susceptible and sustained loss. Race QCCJ carries virulence for Rpgl, which has conferred durable resistance in barley for over 50 years in North America until the appearance of this race in 1988 (21). Since then, it has been a frequent component in the $P$. graminis f. sp. tritici population in North America (3). Race QCCJ is virulent on all barley cultivars grown in Canada and the Upper Midwest region of the United States. Fungicide application is an effective method to reduce infection of stem rust, but is becoming more expensive due to increased petrochemical costs and also is not environmentally friendly. Thus, the most efficient and economic means of control is through the use of host resistance.

Five stem rust genes have been named in barley, of which four provide resistance to $P$. graminis f. sp. tritici. Gene Rpgl is an incubation-temperature insensitive gene derived from 'Chevron'

Corresponding author: T. Fetch, Jr.; E-mail address: Tom.Fetch@agr.gc.ca

doi:10.1094/PHYTO-99-4-0339

( $)$ Her Majesty the Queen in Right of Canada, as represented by the Minister of Agriculture and Agri-Food Canada, 2009.
(CIho 1111) and 'Peatland' (CIho 5267) and has provided durable resistance to most races of $P$. graminis f. sp. tritici in North America (including MCCF) since the release of 'Kindred' barley in 1942 (14,21), but is ineffective to race QCCJ (23). Gene Rpg2 is an adult-plant resistance gene derived from 'Heitpas-5' (9). Heitpas-5 has also displayed seedling resistance to stem rust races HTMJ and JCMN, but is susceptible to most races of stem rust at the seedling stage (23). Gene Rpg3 is derived from PI 382313 and has been reported to possess intermediate levels of seedling resistance (5). It is susceptible to race QCCJ, but is resistant to race $\mathrm{MCCF}$ and several other races (23). The only described gene in barley providing resistance to QCCJ is rpg4, from the breeding line Q21861 (6,7). Q21861 has displayed a high level (IT = 0;1) of resistance to all tested races of wheat stem rust including the highly virulent African race TTKSK (Ug99) (T. Fetch et al., unpublished data), but is sensitive to incubation at high temperatures (7). Gene Rpg5, a dominant gene very closely linked to rpg4 in Q21861, provides resistance to races of rye stem rust (P. graminis f. sp. secalis) (2).

Since the only gene in barley that conditions resistance to race QCCJ is rpg4, a study was conducted in an attempt to identify stem rust resistance in barley lines with introgressions of $H$. bulbosum L. chromatin (4). H. bulbosum is the only species in the secondary gene pool of cultivated barley (1), and resistance to diseases such as powdery mildew (10), leaf rust (13), Septoria speckled leaf blotch (24), leaf scald (20), and barley yellow mosaic virus $(17,18)$ has previously been transferred from $H$. bulbosum into $H$. vulgare. Fetch et al. (4) evaluated 43 recombinant $H$. vulgare lines with introgressions of $H$. bulbosum chromatin and found two (119Y4 and 212Y1) displaying resis- 
tance to race QCCJ. Resistance to race QCCJ is very rare (6); thus the stem rust resistance that was introgressed into 119Y4 and 212 Y1 from $H$. bulbosum may be conditioned by novel gene(s). The seedling infection type (IT) observed in $212 \mathrm{Y} 1\left(10 ; 2^{-}\right)$was lower than 119Y4 (120;), thus 119Y4 was dropped from further testing. The objectives of this study were to (i) determine if the resistance in 212Y1 was different from Q21861 (has rpg4); (ii) determine if the resistance in 212Y1 was different from 'Morex' (has Rpg1); (iii) characterize the inheritance of resistance to stem rust in 212Y1; and (iv) determine the chromosomal location of the $H$. bulbosum introgression in $212 \mathrm{Y} 1$.

\section{MATERIALS AND METHODS}

Germplasm. 212Y1 was a doubled haploid line derived from a triploid hybrid- $H$. vulgare 'Golden Promise' $(2 \mathrm{n}=2 \mathrm{x}=14) / H$. bulbosum Cb2920/4/Colch $(2 \mathrm{n}=4 \times=28)$, which was backcrossed to Golden Promise. 212Y1 was found to possess resistance to stem rust races MCCF (avirulent on Rpgl and rpg4) and QCCJ (virulent on Rpgl and avirulent on rpg4) at the seedling stage in previous glasshouse tests ( $\mathrm{T}$. Fetch, unpublished data). Crosses were subsequently made between 212Y1 and both Morex (Rpg1 [21]) and Q21861 (rpg4 [21]) in Lincoln, New Zealand in 2001. In previous tests, the seedling IT displayed by 212 Y $1(10 ; 2)$ was similar to that of Q21861 $(0 ; 1)$ when inoculated with race QCCJ (4) at $20^{\circ} \mathrm{C}$. Thus, $F_{2}$ seed from $212 \mathrm{Y} 1 / \mathrm{Q} 21861$ was generated at Lincoln and sent to Winnipeg for allelism testing using race QCCJ. For evaluation of inheritance of resistance, five $F_{1}$ seeds from Morex/212Y1 were sent to Winnipeg. Four $F_{1}$ seeds (designated A, B, C, and D) were planted and increased to the $\mathrm{F}_{2}$ generation. Of these, $F_{2}$ progeny from plants $A$ (187 progeny) and $\mathrm{B}$ (188 progeny) were initially selected for testing at the seedling stage for stem rust reaction, with individual $\mathrm{F}_{2}$ plants transplanted into $10 \times 10 \mathrm{~cm}^{2}$ pots and selfed to produce $F_{3}$ seed for subsequent rust evaluation to confirm the $\mathrm{F}_{2}$ seedling reaction. The 212Y1, Morex, and Q21861 parents along with 'Wolfe' (susceptible check) were planted in each experiment as controls. The barley accessions Heitpas-5 (Rpg2 [24]) and PI 382313 (Rpg3 [21]) were also evaluated for their reaction to races MCCF and QCCJ in separate experiments to provide information on their phenotypic response compared to line $212 \mathrm{Y} 1$.

Stem rust phenotyping. For $212 \mathrm{Y} 1 / \mathrm{Q} 21861$ allelism tests, $\mathrm{F}_{2}$ seeds were planted in $10 \times 10 \mathrm{~cm}^{2}$ pots $(20 \mathrm{seeds} / \mathrm{pot})$ filled with Sunshine mix No. 5 (SunGro Horticulture Inc., Seba Beach, Alberta, Canada), and seedlings inoculated at the first leaf fully emerged stage (7 to 8 days old) with race QCCJ according to Sun and Steffenson (23). For Morex/212Y1 genetic experiments, $\mathrm{F}_{2}$ progeny from plants $\mathrm{A}$ and $\mathrm{B}$ were planted into plastic conetainers ( $21 \mathrm{~cm}$ long and $3.8 \mathrm{~cm}$ diameter) filled with Sunshine mix No. 5 (1 seed per cone). Progeny from plant A (187) were inoculated with race MCCF and progeny from plant B (188) were inoculated with race QCCJ, using previously described methods (23). Subsequently, seeds of $\mathrm{F}_{3}$ families were planted in $14 \times 20 \mathrm{~cm}^{2}$ fiber flats (20 seeds/flat) and $F_{3}$ families derived from both plants $A$ (187 families) and B (188 families) were evaluated with races MCCF and QCCJ. All seedling plants were inoculated at the first leaf stage using a concentration of $4.0 \mathrm{mg}$ urediniospores $/ 0.7 \mathrm{ml}$ Bayol oil and incubated using standard protocols (23). Seedlings were rated 14 days later using a modified 0 to 4 IT scale (25) where combinations of ITs $0, ;, 1$, and 2 were classified as a resistant host response, and combinations of $23^{-}$or higher as a susceptible host response. The stem rust reaction in barley is typically mesothetic (has several pustule types), so the IT ratings described in this study indicate the most common pustule type first, followed by the next most common types (22). All $F_{3}$ families were inoculated separately with races MCCF and QCCJ at least twice, with some families repeated a third time so that a final designation (homozygous resistant, segregating, or homozygous susceptible) could be determined.

Statistical tests. Chi-square tests were used to evaluate the independence of segregation for genetic ratios in the $F_{2}$ and $F_{3}$ generations. Homogeneity of segregation ratios among $\mathrm{F}_{3}$ families from plants $\mathrm{A}$ and $\mathrm{B}$ for each race was tested using contingency tables $(2 \times 3)$ and chi-square statistics generated by Fisher's exact test in PROC FREQ using SAS (19). Data for $F_{3}$ families from plants A and B were pooled when the chi-square values were not significant.

Chromosomal location of $\boldsymbol{H}$. bulbosum introgression. Genomic in situ hybridization was done on actively dividing root tip cells to locate the introgression on the short arm of barley chromosome $6 \mathrm{H}(6 \mathrm{HS})$ according to Pickering et al. (11). To confirm the $6 \mathrm{HS}$ location, five polymerase chain reaction (PCR) markers were used to characterize the $H$. bulbosum introgression located in 212Y1 (Primer sequences in Table 1). All PCR markers were amplified using the following cycling conditions: an initial denature of $94^{\circ} \mathrm{C}$ for $2 \mathrm{~min} ; 40$ cycles of $94^{\circ} \mathrm{C}$ for $30 \mathrm{~s}, 55^{\circ} \mathrm{C}$ for $30 \mathrm{~s}$, and $72^{\circ} \mathrm{C}$ for $1 \mathrm{~min}$; and a final extension of $72^{\circ} \mathrm{C}$ for $5 \mathrm{~min}$. Three PCR markers (H31_2522, H31_2318, and H31_24136) were developed from assembly No. 31 of the HarvEST database and were mapped to chromosome $6 \mathrm{HS}$ using the Steptoe/Morex doubled haploid mapping population (8). Primer sequences of two additional markers (KS171, Professor Kazuhiro Sato, Research Institute for Bioresources, Okayama University, Kurashiki, Japan; and GBM1021 [25]) were kindly provided by collaborators. PCR products from all five markers were amplified from four barley lines and four $H$. bulbosum genotypes and were directly sequenced on an ABI3100 Genetic Analyser (Applied Biosystems) using BigDye v3.1 (Applied Biosystems), according to the manufacturer's instructions. Conserved single nucleotide polymorphisms (SNP) between the species were identified and targeted to develop species-diagnostic markers after restriction enzyme digestion for H31_2522 (Tru1I) and H31_2318 (MboI). Restriction digests were performed by adding $5 \mu$ of $1 \times$ Buffer $R$ (Fermentas, Inc., Glen Burnie, MD) containing $1 \mathrm{U}$ of the restriction enzyme (Tru1I or MboI, Fermentas, Inc., Glen Burnie, MD) to a $10-\mu \mathrm{l}$ PCR reaction and incubating at the appropriate temperature $\left(65^{\circ} \mathrm{C} \mathrm{Tru} 1 \mathrm{I}\right.$ or $\left.37^{\circ} \mathrm{C} \mathrm{MboI}\right)$ for $4 \mathrm{~h}$. An aliquot $(5 \mu \mathrm{l})$ of this reaction was then added to an agarose loading buffer and run on $2 \%$ agarose gels to separate the restriction products. The remaining three markers were sequenced directly from PCR products amplified from $212 \mathrm{Y} 1$ to determine whether the barley (Golden Promise) or H. bulbosum (Cb2920/4/Colch) allele was present at these loci.

\section{RESULTS}

Allelism tests with Q21861. Infection levels on 212Y1/ Q21861 $F_{2}$ plants, 212Y1, Q21861, and Wolfe were uniform, but

TABLE 1. Primer sequences of barley chromosome 6HS polymerase chain reaction markers

\begin{tabular}{|c|c|c|}
\hline Marker name & Forward primer & Reverse primer \\
\hline H31_2522 & GTTGGAGTKATTGGAGCTG & GTGGAYTGGTAMAGATCAAAGTAG \\
\hline H31_2318 & CCGGTGAAGATCTCCAAGAA & GTGTAGACGAGGCGCTTGAC \\
\hline H31_24136 & GGTCTCAGCTCCTCTTCTACCTC & AATGCAGATAAAATATGAAGAGCTTG \\
\hline $\mathrm{KS} 1 \overline{7} 1$ & CGTCGATGACTCTTCTTCAGG & TGTGATGAGGCACCTTTATTTC \\
\hline GBM1021 & GGTTCTGATCAAGGAACCTTTT & TCAAATATACGCCCTCCGTC \\
\hline
\end{tabular}


ITs were lower than normal due to cool mean $\left(18^{\circ} \mathrm{C}\right)$ incubation temperatures in the greenhouse that occurred in January. Q21861 displayed a highly resistant seedling response (IT $=0 ; 1$, indicating mostly 0 ; reactions with some small IT $=1$ pustules present), while $212 \mathrm{Y} 1$ had a moderately resistant response (IT = $10 ; 2$, indicating mostly IT $=1$ pustules were present along with some 0 ; and some IT $=2$ pustules). Wolfe had a moderately susceptible response $\left(\mathrm{IT}=23^{-} 1\right.$, indicating mostly IT $=2$ type pustules along with IT $=3$ and some IT $=1$ pustules) due to incubation at $18^{\circ} \mathrm{C}$. Although most progeny had resistant to intermediate responses to infection with race QCCJ, susceptible $F_{2}$ progeny were clearly identified from the $212 \mathrm{Y} 1 / \mathrm{Q} 21861$ population.

Inheritance of resistance in 212Y1. Infection on $F_{2}$ progeny from Morex/212Y1 $\mathrm{F}_{1}$ plants $\mathrm{A}$ and $\mathrm{B}$ was very poor with many plants escaping infection, which was attributed to an inadvertent exposure to propiconazole that was applied to plants in an adjoining greenhouse room. Thus, $\mathrm{F}_{2}$ progeny from two additional $\mathrm{F}_{1}$ plants $(\mathrm{C}$ and $\mathrm{D})$ were inoculated with races $\mathrm{MCCF}$ and QCCJ, respectively. $F_{2}$ Progeny from plant $C$ (90 lines) that were inoculated with race MCCF fit a 13 resistant: 3 susceptible ratio, and $\mathrm{F}_{2}$ progeny from plant $\mathrm{D}$ (90 lines) inoculated with race QCCJ fit a 1 resistant: 3 susceptible ratio (Table 2). Infection on Morex/212Y1 $\mathrm{F}_{3}$ families was generally uniform and results are summarized in Table 2. In some cases, a third replicate of testing on specific $\mathrm{F}_{3}$ families was conducted in order to determine a final classification. Tests of homogeneity of segregation ratios among replicated $\mathrm{F}_{3}$ populations were nonsignificant using $2 \times 3$ contingency tables $\left(\chi^{2}=0.009, P=0.995\right.$ for race QCCJ, $\chi^{2}=0.026$, $P=0.987$ for race MCCF), so $\mathrm{F}_{3}$ data could be pooled by race.

Both Morex (IT $=0 ; 1^{-}$) and 212Y1 (IT = 120;) had low responses to race $\mathrm{MCCF}$ at $22^{\circ} \mathrm{C}$, and Wolfe showed a susceptible $\left(\mathrm{IT}=3^{-2}\right)$ response. Segregation data for $\mathrm{F}_{3}$ families evaluated with race MCCF fit a 7:8:1 (homozygous resistant [HR]: Segregating [Seg]: homozygous susceptible [HS]) ratio (Table 2). Segregating families (20 plants per family evaluated) with $3 R: 1 S$ (resistant plants with IT $=0 ; 1$ ), 13R:3S (resistant plants with mostly IR $=0 ; 1$ but some IT $=120$;), and $1 \mathrm{R}: 3 \mathrm{~S}$ (resistant plants with only $I R=120$;) ratios were found. About three in four families were $3 \mathrm{R}: 1 \mathrm{~S}$ or $13 \mathrm{R}: 3 \mathrm{~S}$, and one in four $\mathrm{F}_{3}$ families were $1 \mathrm{R}: 3 \mathrm{~S}$.

Seedling responses at $21^{\circ} \mathrm{C}$ to race QCCJ were differential between Morex (IT = 3-32) and 212Y1 (IT = 120;), and Wolfe showed a susceptible (IT $=3^{-23}$ ) response. Segregation data for $\mathrm{F}_{3}$ families evaluated with race QCCJ fit a 1:2:1 (HR: Seg: HS) ratio (Table 2). Segregating families (20 plants per family evaluated) from both populations generally followed a $1 \mathrm{R}: 3 \mathrm{~S}$ ratio.

Location of introgression of $\boldsymbol{H}$. bulbosum chromatin. After doing genomic in situ hybridization on root tip cells of 212Y1, two signals were seen on the short arm of two chromosomes with large satellites (Fig. 1). The size of the satellites indicated that the chromosome was $H$. vulgare $6 \mathrm{H}$, and the introgression was distally located on the short arm (6HS). PCR markers distally located on chromosome 6HS confirmed this finding. DNA from
212Y1 produced homozygous $H$. bulbosum patterns for both H31_2522 (digested with Tru1I [TTAA] and H31_2318 [digested with $M b o$ I GATC]) (Fig. 2). Direct sequencing of PCR amplification products from two more proximal markers (H31_24136 [KS338] and KS171, Fig. 3) and multiple sequence alignment using SeqScape (Applied Biosystems) indicated that sequences from 212 Y1 completely matched the sequences generated from its $H$. bulbosum parental genotype (2920/4) for these markers (data not shown). Only GBM1021 was determined to be proximal to the introgressed chromatin in $212 \mathrm{Y} 1$, as its amplification product resembled that of the barley parent Golden Promise (data not shown). This indicates that the genetic size of the introgressed region from $H$. bulbosum on chromosome 6HS was less than $40 \mathrm{cM}$, or approximately $29 \%$ of the length of barley chromosome 6H (Fig. 3).

\section{DISCUSSION}

This is the first report of the transfer of stem rust resistance from $H$. bulbosum into $H$. vulgare and adds to the extensive suite of resistance genes that are available to breeders from a species in the secondary genepool. Previous assessment of barley lines with $H$. bulbosum introgressions found that $212 \mathrm{Y} 1$ possessed levels of resistance to race QCCJ that was similar to line Q21861 (4). The allelism test in this study between Q21861 and 212Y1 found susceptible $F_{2}$ progeny, so the resistance gene in $212 \mathrm{Y} 1$ is different from rpg4. Furthermore, since the gene in 212Y1 was positioned to chromosome 6HS and gene rpg4 is on 5HL (2), they are independently inherited. This means that a novel source of resistance to race QCCJ from 212Y1 is available to barley breeders.

The Morex/212Y1 cross was made both to perform allelism tests to Rpgl and for characterization of the inheritance of resistance in $212 \mathrm{Y} 1$. Segregation of $F_{2}$ progeny and $F_{3}$ families fit a two-gene ratio with dominant and recessive ratios in segregating $\mathrm{F}_{3}$ families when inoculated with race MCCF. Morex has Rpgl, which is a dominant gene that is located on chromosome 7HS (26), thus the second gene conditioning recessive inheritance is attributed to $212 \mathrm{Y} 1$. Segregation of $F_{2}$ progeny and $F_{3}$ families fit a one-gene ratio with a recessive ratio in $\mathrm{F}_{3}$ families when inoculated with QCCJ. Since Rpgl is ineffective to race QCCJ (21) but 212Y1 was resistant, this provides further evidence for a single recessive gene in $212 \mathrm{Y} 1$. Additionally, since the gene in $212 \mathrm{Y} 1$ is on chromosome 6HS and Rpgl is on 7HS, they are independent.

The locus rpg6 is proposed for the novel recessive gene in 212Y1. In this study, 212Y1 was tested for allelism to Rpgl and rpg4 and found to be independent to both genes. Allelism tests between the recessive gene in 212Y1 with Rpg 2 and Rpg 3 were not conducted because we did not have an avirulent pathotype of $P$. graminis f. sp. tritici to either gene at the seedling stage at the start of the study. In our study, Heitpas 5 (Rpg2) was susceptible $\left(\mathrm{IT}=3^{-2}\right)$ to both races QCCJ and MCCF, while PI 382313 (Rpg3) was susceptible (IT $=3^{-} 2$ ) to race QCCJ and intermediate $(\mathrm{IT}=213-)$ to race MCCF. Sun and Steffenson (23) recently

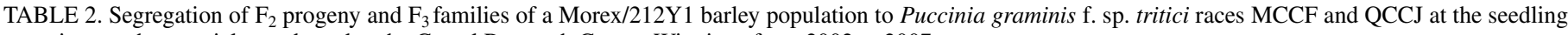
stage in greenhouse trials conducted at the Cereal Research Centre, Winnipeg from 2002 to 2007

\begin{tabular}{|c|c|c|c|c|c|c|c|c|}
\hline Generation $^{\mathrm{a}}$ & $\mathrm{F}_{1}$ Plant & Race & Resistant & Segregating & Susceptible & Model & $\chi^{2}$ value & $P$ value \\
\hline $\mathrm{F}_{2}$ & $\mathrm{C}$ & MCCF & 70 & & 20 & $13: 3$ & 0.712 & $0.3988 \mathrm{NS}$ \\
\hline $\mathrm{F}_{3}$ & A & MCCF & 87 & 88 & 12 & $7: 8: 1$ & 0.661 & $0.7186 \mathrm{NS}$ \\
\hline $\mathrm{F}_{3}$ & B & $\mathrm{MCCF}$ & 86 & 90 & 12 & $7: 8: 1$ & 0.347 & $0.8407 \mathrm{NS}$ \\
\hline $\mathrm{F}_{3}$ & Pooled & $\mathrm{MCCF}$ & 173 & 178 & 24 & $7: 8: 1$ & 0.982 & $0.6120 \mathrm{NS}$ \\
\hline $\mathrm{F}_{2}$ & $\mathrm{D}$ & QCCJ & 19 & & 71 & $1: 3$ & 0.726 & $0.3942 \mathrm{NS}$ \\
\hline $\mathrm{F}_{3}$ & A & QCCJ & 40 & 103 & 44 & $1: 2: 1$ & 2.102 & $0.3496 \mathrm{NS}$ \\
\hline $\mathrm{F}_{3}$ & B & QCCJ & 40 & 103 & 45 & $1: 2: 1$ & 1.989 & $0.3699 \mathrm{NS}$ \\
\hline $\mathrm{F}_{3}$ & Pooled & QCCJ & 80 & 206 & 89 & $1: 2: 1$ & 4.083 & $0.1298 \mathrm{NS}$ \\
\hline
\end{tabular}

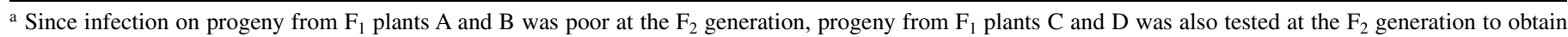
segregation data. 


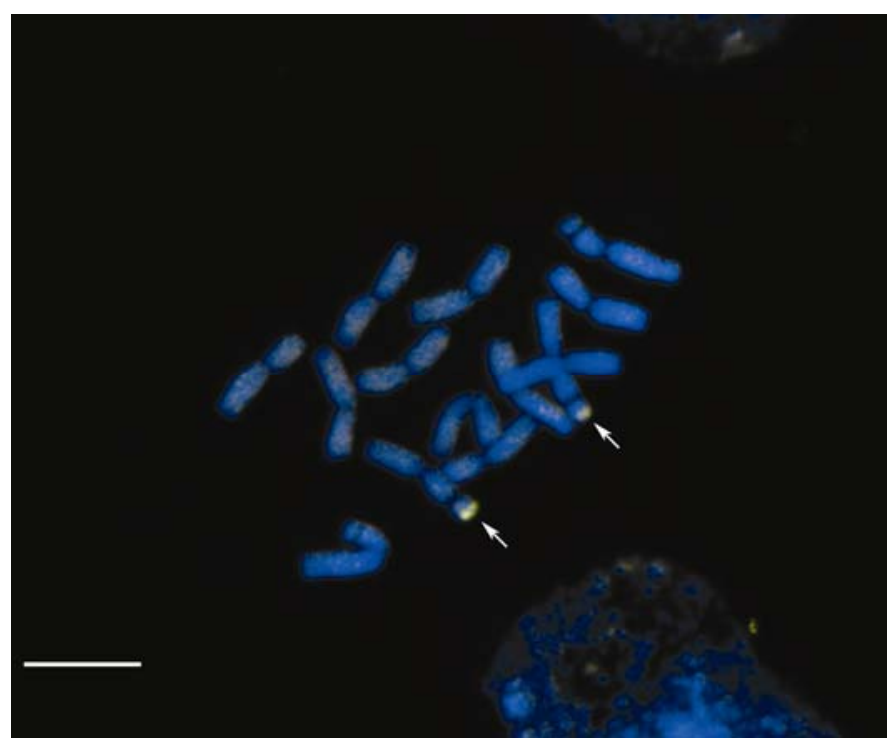

Fig. 1. Genomic in situ hybridization image of a mitotic cell preparation taken from an actively dividing root tip cell of $212 \mathrm{Y} 1$ showing two signals on the short arms of two barley chromosomes with large satellites (chromosome $6 \mathrm{HS}) . \mathrm{Bar}=10 \mu \mathrm{m}$

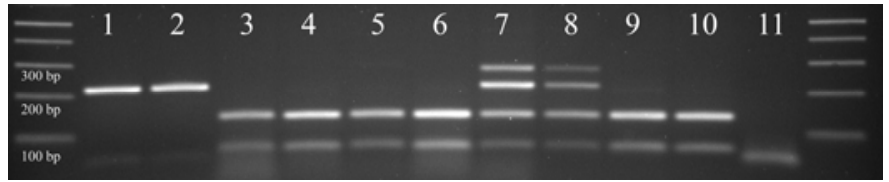

Fig. 2. Cleaved amplified polymorphic sequence (CAPS) marker H31_2522 which amplifies a 218 bp product in all barley cultivars and all Hordeum bulbosum genotypes tested. Restriction digestion with the enzyme TrulI (TTAA) produces two products $(146+72 \mathrm{bp})$ in the $H$. bulbosum genotypes 2920/4 and A17 (lanes 9 and 10) with the barley cultivars Golden Promise and Emir remaining undigested (lanes 1 and 2). Lanes 3 and 4 are replicates of 212Y1, lanes 5 and 6 are unrelated 6HS introgression lines 119Y4 and 174Q1, lane 7 is a $6 \mathrm{Hb}$ chromosome substitution line (34L71), lane 8 is the interspecific hybrid 204K3 (heterozygotes displaying an additional heteroduplex band larger than the barley parental band), lane 11 is a no template control, and flanking lanes are DNA ladder

described pathotype JCMN as avirulent to both $R p g 2$ and $R p g 3$, thus this race could be used for future allelism and genetic studies. Since the genes Rpg2 and Rpg 3 are dominant and both are ineffective to races MCCF and QCCJ (Rpg3 is intermediate), and gene rpg6 is recessive and effective to races MCCF and QCCJ, it is unlikely that $r p g 6$ is allelic to either Rpg2 or Rpg3.

Additional seedling tests have indicated that $r p g 6$ is not effective against the highly virulent African race TTKSK (T. Fetch, unpublished data), but we have no data on the adult plant response of $212 \mathrm{Y} 1$ to this race. In previous work with Puccinia hordei G. Otth., some H. vulgare-H. bulbosum introgression lines exhibited a susceptible seedling infection type, but a low incidence of disease at a later developmental stage (12). Hence, it is conceivable that $212 \mathrm{Y} 1 \mathrm{might}$ possess similar resistance and needs to be evaluated at the adult plant stage to particularly virulent stem rust races. The durability of these resistances will only become clear after extensive growing over a period of years of new barley cultivars containing these genes. Because linkage drag of deleterious traits is often associated with introgressed DNA from wild related species, it would be advantageous to shorten the length of the introgressed segment from H. bulbosum if possible. However, the precise location of the resistance locus will only be determined by screening a large segregating population derived from 212Y1 and a susceptible barley cultivar. Studies are in progress to resolve this, and when finished will be
A

B

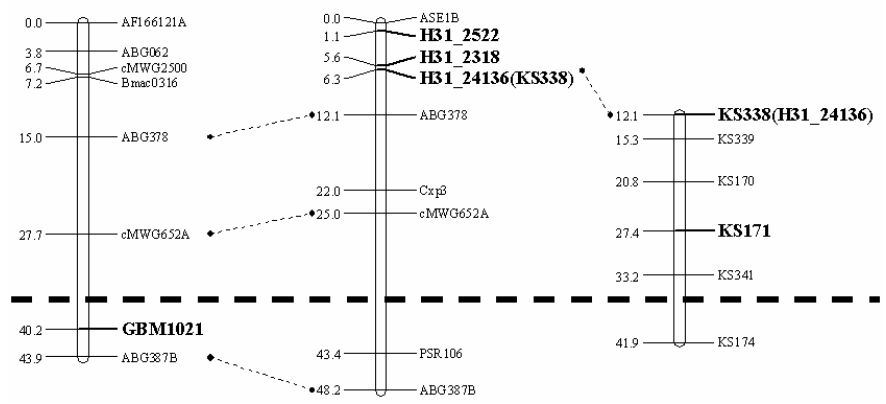

Fig. 3. Genetic linkage maps indicating the relative positions of markers used during analysis (indicated in bold). Connectors indicate markers common between maps, and dashed line indicates the likely proximal end of the Hordeum bulbosum introgression in 212Y1 (A, consensus map [28], B, Steptoe $\times$ Morex map [9], and $\mathbf{C}$, doubled haploid population [n = 93]) between the barley cv. Haruna Nijo and the H. spontaneum genotype $\mathrm{H} 602$ (K. Sato, personal communication).

beneficial to barley breeding programs in providing information that will aid in reducing the size of the introgression while retaining the novel gene rpg6 that is described in this study.

\section{ACKNOWLEDGMENTS}

We thank K. Sato, Research Institute for Bioresources, Okayama University, Kurashiki, 710-0046, Japan for permission to use the chromosome 6HS map in Figure 3, and his primer sequences to carry out the molecular marker analyses. We also thank K. Dunsmore and C. LeClerc for their excellent technical assistance in the stem rust phenotyping of the Morex/212Y1 populations. This is contribution number 1966 of the Cereal Research Centre

\section{LITERATURE CITED}

1. Bothmer, R. von, Jacobsen, N., Baden, C., Jorgensen, R. B., and LindeLaursen, I. 1995. An Ecogeographical Study of the Genus Hordeum. 2nd ed. Intl. Plant Genet. Res. Inst., Rome, Italy.

2. Brueggeman, R., Druka, A., Nirmala, J., Cavileer, T., Drader, T., Rostoks, N., Mirlohi, A., Bennypaul, H., Gill, U., Kudrna, D., Whitelaw, C., Kilian, A., Han, F., Sun, Y., Gill, K., Steffenson, B., and Kleinhofs, A. 2008. The stem rust resistance gene $R p g 5$ encodes a protein with nucleotidebinding-site, leucine-rich, and protein kinase domains. P. Natl. Acad. Sci. 105:14970-14975.

3. Fetch, T. G., Jr. 2005. Races of Puccinia graminis on wheat, barley, and oat in Canada, in 2002 and 2003. Can. J. Plant Pathol. 27:572-580.

4. Fetch, T., Pickering, R., and Johnston, P. 2004. Novel stem rust resistance in barley lines with introgressions of Hordeum bulbosum chromatin. Proc. 11th Intl. Cereal Rusts \& Powdery Mildews Conf. Abstract 2.18, Cereal Rusts and Powdery Mildews Bulletin. Published online. www.crpmb.org/ icrpmc11/abstracts.htm.

5. Jedel, P. E. 1990. A gene for resistance to Puccinia graminis f. sp. tritici in PI 382313. Barley Genet. Newsl. 20:43-44.

6. Jin, Y., Steffenson, B. J., and Fetch, T. G., Jr. 1994. Sources of resistance to pathotype QCC of Puccinia graminis f. sp. tritici in barley. Crop Sci. $34: 285-288$

7. Jin, Y., Steffenson, B. J., and Miller, J. D. 1994. Inheritance of resistance to pathotypes QCC and MCC of Puccinia graminis $\mathrm{f}$. sp. tritici in barley line Q21861 and temperature effects on the expression of resistance. Phytopathology 84:452-455.

8. Kleinhofs, A., Killian, A., Saghai-Maroof, M., Biyashev, R., Hayes, P., Chen, F., Lapitan, N., Fenwick, A., Blake, T., Kanazin, V., Ananiev, E., Dahleen, L., Kudrna, D., Bollinger, J., Knapp, S., Liu, B., Sorrells, M., Heun, M., Franckowiak, J., Hoffman, D., Skadsen, R., and Steffenson, B. 1993. A molecular, isozyme, and morphological map of the barley (Hordeum vulgare) genome. Theor. Appl. Genet. 86:705-712.

9. Patterson, F. L., Shands, R. G., and Dickson, J. G. 1957. Temperature and seasonal effects on seedling reactions of barley varieties to three races of Puccinia graminis f. sp. tritici. Phytopathology 47:395-402.

10. Pickering, R. A., Hill, A. M., Michel, M., and Timmerman-Vaughan, G. M. 1995. The transfer of a powdery mildew resistance gene from Hordeum bulbosum L. to barley (H. vulgare L.) chromosome 2 (2I). 
Theor. Appl. Genet. 91:1288-1292.

11. Pickering, R. A., Malyshev, S., Künzel, G., Johnston, P. A., Korzun, V., Menke, M., and Schubert, I. 2000. Locating introgressions of Hordeum bulbosum chromatin within the $H$. vulgare genome. Theor. Appl. Genet. 100:27-31.

12. Pickering, R., Niks, R. E., Johnston, P. A., and Butler, R. C. 2004. Importance of Secondary and Tertiary Genepools in Barley Genetics and Breeding. II. Disease Resistance, Agronomic Performance and Quality. Czech J. Genet. Plant Breed. 40:79-85.

13. Pickering, R. A., Steffenson, B. J., Hill, A. M., and Borokova, I. 1998. Association of leaf rust and powdery mildew resistance in a recombinant derived from a Hordeum vulgare $\times$ Hordeum bulbosum hybrid. Plant Breed. 117:83-84.

14. Powers, L., and Hines, L. 1933. Inheritance of reaction to stem rust and barbing of awns in barley crosses. J. Agr. Res. 46:1121-1129.

15. Roelfs, A. P. 1978. Estimated losses caused by rust in small grain cereals in the United States - 1918-76. U.S. Dept. Agric. Misc. Publ. 1363.

16. Roelfs, A. P. 1985. Wheat and rye stem rust. Pages 3-37 in: The Cereal Rusts. Vol II. Diseases, Distribution, Epidemiology, and Control. A. P. Roelfs and W. R. Bushnell (eds.). Academic Press, Inc. New York.

17. Ruge, B., Linz, A., Pickering, R., Proeseler, G., Greif, P., and Wehling, P. 2003. Mapping of Rym $14^{\mathrm{Hb}}$, a gene introgressed from Hordeum bulbosum and conferring resistance to BaMMV and BaYMV in barley. Theor. Appl. Genet. 107:965-971.

18. Ruge-Wehling, B., Linz, A., Habekuß, A., and Wehling, P. 2006. Mapping of $R y m 16^{\mathrm{Hb}}$, the second soil-borne virus-resistance gene introgressed from
Hordeum bulbosum. Theor. Appl. Genet. 113:867-873.

19. SAS Institute Inc. 2004. SAS OnlineDoc 9.1.3. SAS Institute Inc., Cary, $\mathrm{NC}$.

20. Singh, A. K., Rossnagel, B. G., Scoles, G. J., and Pickering, R. A. 2004. Identification of a quantitatively inherited source of Hordeum bulbosum derived scald resistance from barley line 926K2/11/1/5/1. Can. J. Plant Sci. 84:935-938.

21. Steffenson, B. J. 1992. Analysis of durable resistance to stem rust in barley. Euphytica 63:153-167.

22. Steffenson, B. J., Miller, J. D., and Jin, Y. 1993. Detection of the stem rust resistance gene Rpg1 in barley seedlings. Plant Dis. 77:626-629.

23. Sun, Y., and Steffenson, B. J. 2005. Reaction of barley seedlings with different stem rust resistance genes to Puccinia graminis f. sp. tritici and Puccinia graminis f. sp. secalis. Can. J. Plant Pathol. 27:80-89.

24. Toubia-Rahme, H., Johnston, P. A., Pickering, R. A., and Steffenson, B. J. 2003. Inheritance and chromosomal location of Septoria passerinii resistance introgressed from Hordeum bulbosum into Hordeum vulgare. Plant Breed. 122:405-409.

25. Varshney, R., Marcel, T., Ramsay, L., Russell, J., Röder, M., Stein, N., Waugh, R., Langridge, P., Niks, R., and Graner, A. 2007. A high density barley microsatellite consensus map with 775 SSR loci. Theor. Appl. Genet. 114:1091-1103.

26. Zhang, L., Fetch, T., Nirmala, J., Schmierer, D., Brueggeman, R., Steffenson, B., and Kleinhofs, A. 2006. Rpr1, a gene required for Rpg1dependent resistance to stem rust in barley. Theor. Appl. Genet. 113:847855. 